\title{
ANTIBIOTIC AB-64, A NEW INDICATOR-PIGMENT ANTIBIOTIC FROM ACTINOMADURA ROSEOVIOLACEA VAR. RUBESCENS
}

\author{
Atsushi Tamura, Ryuji furuta, Hirotada Kotani \\ and Shunsuke Naruto \\ Research \& Development Division, Dainippon Pharmaceutical Co., Ltd., \\ Suita, Osaka, Japan \\ (Received for publication April 16, 1973)
}

\begin{abstract}
A new antibiotic designated as antibiotic AB-64 inhibiting gram-positive bacteria was isolated from a rare Actinomycete. The producing strain was classified as Actinomadura roseoviolacea var. rubescens. Antibiotic AB-64, obtained as red powder, has a molecular

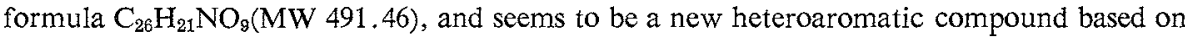
its physical and chemical properties.
\end{abstract}

During the course of screening for new antibiotics from rare actinomycetes in our laboratory, a rare actinomycete initially designated as strain A-3416 was found to produce an antibiotic with strong activity against staphylococci resistant to various antibiotics. From its unique physicochemical properties, it was judged to be a new antibiotic and named antibiotic AB-64.

In this paper, taxonomical studies of strain A-3416, fermentation, isolation and characterization of antibiotic AB-64 are described.

\section{Taxonomical Studies on Strain A-3416}

Strain A-3416, that produces antibiotic AB-64, was isolated from a soil collected at Hikami, Hyogo Prefecture, Japan. According to the taxonomical studies described below, this organism was identified with a new variant of Actinomadura roseoviolacea ${ }^{1)}$ and designated as Actinomadura roseoviolacea var. rubescens nov. var. TAMURA et KotANI. It shows the following properties:

1. Morphological Properties

The morphology of the culture on maltyeast agar was microscopically observed (Plates 1 and 2).

Plate 1. Aerial mycelium of $A$. roseoviolacea var. rubescens A-3416 on glycerol-asparagine agar-V after 21 days.

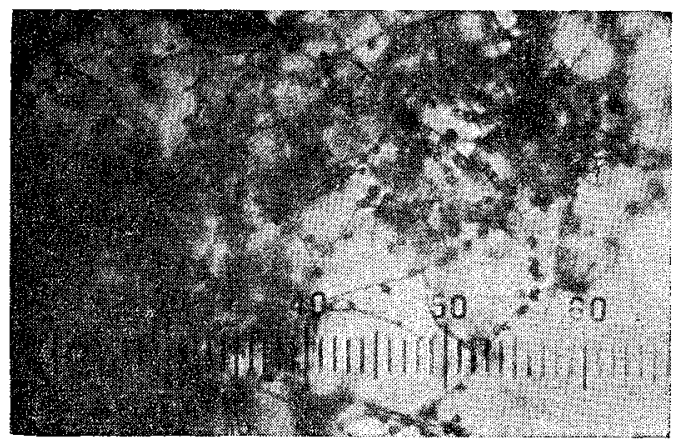

Plate 2. Electron-micrograph of spores of $A$. roseoviolacea var. rubescens A-3416 on malt-yeast agar after 30 days.

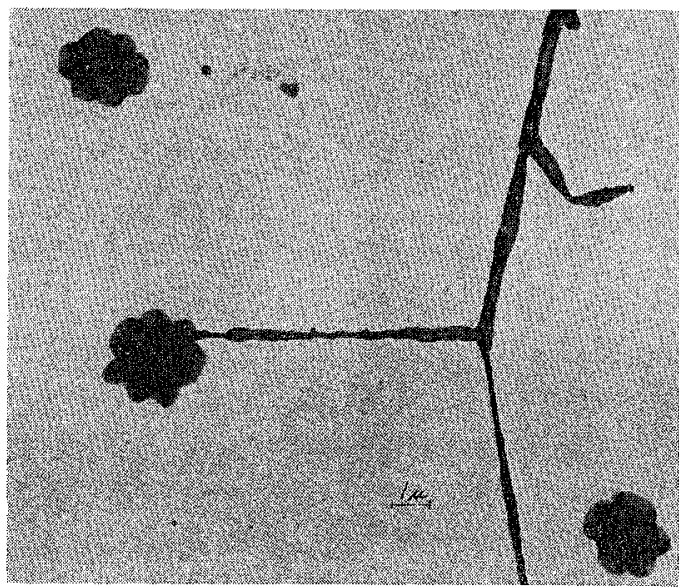


Table 1. Cultural properties of strain A-3416

\begin{tabular}{|c|c|c|c|}
\hline Medium & Growth & Aerial mycelium & Soluble pigment \\
\hline Sucrose-nitrate agar & $\begin{array}{l}\text { Moderate, scant spreading, } \\
\text { cream }\left(1 \frac{1}{2} \mathrm{ca}\right)^{* *}\end{array}$ & None & None \\
\hline Sucrose-nitrate agar-V* & $\begin{array}{l}\text { Moderate, scant spreading, Lt. } \\
\text { coral rose ( } 6 \mathrm{ga}) \text { with small red } \\
\text { patches }\end{array}$ & $\begin{array}{l}\text { Moderate, powderly, } \\
\text { brite shell pink ( } 6 \text { ea) }\end{array}$ & None \\
\hline Glucose-asparagine agar-V & $\begin{array}{l}\text { Moderate, scant spreading, } \\
\text { rust brown ( } 5 \mathrm{pg})\end{array}$ & None & None \\
\hline Glycerol-asparagine agar & Scant growth, spreading, white & None & None \\
\hline Glycerol-asparagine agar-V & $\begin{array}{l}\text { Moderate, raised, brown } \\
\text { mahogani ( } 6 \mathrm{pi})\end{array}$ & $\begin{array}{l}\text { Moderate, powderly, } \\
\text { pale pink ( } 6 \mathrm{ca})\end{array}$ & $\begin{array}{l}\text { Pale light } \\
\text { brown }\end{array}$ \\
\hline Starch agar-V & $\begin{array}{l}\text { Thin, small colonies, not } \\
\text { spreading, persimmon }(5 \mathrm{nc})\end{array}$ & None & None \\
\hline Tyrosine agar- $\mathrm{V}$ & $\begin{array}{l}\text { Moderate, raised, rust brown } \\
(5 \mathrm{pg})\end{array}$ & $\begin{array}{l}\text { Moderate powderly, } \\
\text { pale pink }(6 \mathrm{ca})\end{array}$ & None \\
\hline Bouillon agar & $\begin{array}{l}\text { Moderate, wrinkled, melon } \\
\text { yellow ( } 3 \text { ea) }\end{array}$ & None & None \\
\hline Malt-yeast agar & $\begin{array}{l}\text { Abundant, raised, terra cotta } \\
\text { ( } 5 \text { pe) }\end{array}$ & $\begin{array}{l}\text { Abundant, powderly, } \\
\text { pale pink ( } 6 \mathrm{ca})\end{array}$ & None \\
\hline Oatmeal agar & $\begin{array}{l}\text { Abundant, flat, lacquer red } \\
(6 \text { pe) }\end{array}$ & $\begin{array}{l}\text { Scant powderly, white } \\
\text { or shell pink }\end{array}$ & None \\
\hline Milk-V & Moderate, ring, sunset red (6 la) & None & None \\
\hline Peptone-yeast-iron agar & $\begin{array}{l}\text { Abundant wrinkled, shell pink } \\
(5 \mathrm{pa})\end{array}$ & None & None \\
\hline $\begin{array}{l}\text { Glycerol-calcium malate } \\
\text { agar-V }\end{array}$ & $\begin{array}{l}\text { Moderate, flat, Dk. lacquer red } \\
(6 \text { pe) }\end{array}$ & None & None \\
\hline
\end{tabular}

Glucose-asparagine agar, starch agar, tyrosine agar and glucose-peptone-gelatin-V: no growth or scant growth.

* $-\mathrm{V}$ : added B-vitamins').

** Color No. on Color Harmony Manual (1958).

Spore chains, spirals, thightly closed and forming pseudosporangia on long aerial hyphae. Pseudosporangia usually about $3 \sim 5 \mu$ diameter. Spores seemed to be enveloped in slimy substance. Spore surface: smooth.

\section{Cultural Properties}

The cultural properties on different media are listed in Table 1. The experiments to determine the following cultural characteristics were carried out at $30^{\circ} \mathrm{C}$ for $3 \sim 4$ weeks. The gelatin stab culture was observed after incubation at room temperature for 60 days.

3. Carbon Utilization

The carbon utilization of strain A-3416 was examined according to the method described by NONOMURA and OHARA ${ }^{2)}$ with results as shown in Table 2.

4. Physiological Properties

The physiological properties are summarized in Table 3. 
5. Cell Wall Components

Amino acids and carbohydrates from cell wall hydrolysates were examined according to the method described by Boone and PINE ${ }^{3)}$.

Amino acids: meso-diaminopimelic acid (present), lysine (none).

Sugars: arabinose (none), galactose (none), xylose (none).

The distinctive characters of strain A-3416 are as follows:

Table 2. Carbon utilization of strain A-3416 (C-2 medium $\left.{ }^{2}\right)$

\begin{tabular}{|c|c|}
\hline Carbon source & Results \\
\hline No carbon & \pm \\
\hline L-Arabinose & \pm \\
\hline $\mathrm{D}-\mathrm{Xylose}$ & + \\
\hline D-Glucose & $H$ \\
\hline D-Fructose & $H$ \\
\hline Sucrose & H \\
\hline Inositol & H \\
\hline L-Rhamnose & + \\
\hline Raffinose & H \\
\hline D-Mannitol & $H$ \\
\hline Salicin & + \\
\hline$\alpha$-Methyl-glucoside & + \\
\hline Galactose & $H$ \\
\hline Lactose & + \\
\hline Cellulose & \pm \\
\hline
\end{tabular}

(1) Cell wall components: Type III $^{4)}$ (Thermoactinomyces, Actinobifida, Microbispora and Actinomadura).

(2) Melanoid pigments not produced (in the sense of ISP $^{57}$ ).

(3) Spore chains: tightly closed spirals or pseudosporangia. Spore surface: smooth.

(4) Aerial mass color: pale pink.

(5) Substrate mycelium: red ( $\mathrm{pH}$ sensitive).

From the taxonomical studies performed and the key to the new species of Actinoma$d u r a^{1}$, it is evident that strain A-3416 should be classified in the genus Actinomadura, and strain A-3416 most closely resembles Actinomadura roseoviolacea A-5 (Nonomura and OhARA, 1971) ${ }^{11}$. However, detailed comparison experiment, which was pointed out by H. NonOMura (personal communication, Jan. 1972), show some differences between strain A-3416 and $A$.

Table 3. Physiological properties of strain A-3416

\begin{tabular}{|c|c|c|}
\hline Determination & Results & Medium used \\
\hline Melanoid pigment & Negative & $\begin{array}{l}\text { Peptone-yeast-iron agar, Tyro- } \\
\text { sine agar-V }\end{array}$ \\
\hline Starch hydrolysis & Positive & Starch agar-V \\
\hline Nitrite from nitrate & Positive & Nitrate broth \\
\hline Milk peptonization & Positive & $\begin{array}{l}10 \% \text { Difco skim milk (after } 3 \\
\text { weeks) }\end{array}$ \\
\hline Gelatin liquefaction & Weakly positive & $\begin{array}{l}\text { Glucose-peptone-gelatin-V } \\
\text { (after } 60 \text { days) }\end{array}$ \\
\hline Production of $\mathrm{H}_{2} \mathrm{~S}$ & Weakly positive & Peptone-yeast-iron agar \\
\hline Solubility of Ca-malate & Positive & Glycerol-Ca malate agar-V \\
\hline Relation to temperature & $\begin{array}{l}\text { Optimum growth at } 32 \sim \\
34^{\circ} \mathrm{C} \text {, no growth at } 45^{\circ} \mathrm{C}\end{array}$ & Malt-yeast broth \\
\hline Relation to $\mathrm{pH}$ of medium & $\begin{array}{l}\text { Optimum growth at } \mathrm{pH} \\
6 \sim 8\end{array}$ & Malt-yeast broth \\
\hline B-vitamins & Essential for growth & \\
\hline
\end{tabular}


Table 4. Comparison of strain A-3416 and A. roseoviolacea A-5

\begin{tabular}{|c|c|c|c|}
\hline & & Strain A-3416 & A. roseoviolacea A-5 \\
\hline \multicolumn{2}{|c|}{$\begin{array}{l}\text { Color change of colony (reverse side) by addition of } \\
0.05 \mathrm{~N} \mathrm{NaOH}{ }^{1} \text { on yeast-malt agar, oatmeal agar } \\
\text { and glycerol-asparagine agar- } \mathrm{V} \text { after } 30 \text { days. }\end{array}$} & $\begin{array}{l}\text { from rust brown (or } \\
\text { brown red) to deep } \\
\text { ruby red }\end{array}$ & $\begin{array}{l}\text { from dark purple (or } \\
\text { dull red) to violet }\end{array}$ \\
\hline \multirow[t]{10}{*}{ Hydrolysis of } & Casein $^{2)}$ & + & + \\
\hline & Xanthine 3 ) & - & - \\
\hline & Hypoxanthine & & \\
\hline & $\longrightarrow$ xanthine ${ }^{3)}$ & + & + \\
\hline & Adenine & & \\
\hline & $\rightarrow$ hypoxanthine ${ }^{3)}$ & - & + \\
\hline & Tyrosine 4 & + & + \\
\hline & $\operatorname{Starch}^{5\rangle}$ & + & + \\
\hline & Esculine ${ }^{6)}$ & + & + \\
\hline & Urea ${ }^{7)}$ & - & - \\
\hline \multicolumn{2}{|c|}{ Nitrite from nitrate 1 ) } & + & + \\
\hline \multirow{6}{*}{$\begin{array}{l}\text { Acid production } \\
\left.\text { from }^{8}\right)\end{array}$} & Arabinose & + & + \\
\hline & Erythritol & - & - \\
\hline & Mannitol & $(+)$ & - \\
\hline & Melibiose & + & + \\
\hline & Rhamnose & + & + \\
\hline & Xylose & + & $(+)$ \\
\hline
\end{tabular}

1) ISP methods).

2) Starch- $\mathrm{K}_{2} \mathrm{HPO}_{4}-\mathrm{V}$ (soluble starch $10 \mathrm{~g}, \mathrm{~K}_{2} \mathrm{HPO}_{4} 0.5 \mathrm{~g}, \mathrm{~B}$-vitamins, water liter, $\mathrm{pH} 7.0$ ). Casein $1 \mathrm{~g} / \mathrm{liter}$. Detection: Avicel (cellulose) TLC, EtOH-water $(7: 3)$, ninhydrin reaction.

3) Trypton-yeast broth (ISP medium 1) and starch- $\mathrm{K}_{2} \mathrm{HPO}_{4}-\mathrm{V}$. Test sample $1 \mathrm{~g} / \mathrm{liter}$.

Detection: Avicel TLC, water saturated $n-\mathrm{BuOH}-\mathrm{NH}_{4} \mathrm{OH}(100: 1)$, UV light $(280 \mathrm{~nm})$.

4) Trypton-yeast broth. Tyrosine $1 \mathrm{~g} /$ liter.

Detection: Avicel TLC, $n$-BuOH-acetic acid-water $(4: 1: 2), \alpha$-nitroso- $\beta$-naphtol, ninhydrin, MILLuN reaction.

5) Trypton-yeast broth. Soluble starch $1 \mathrm{~g} /$ liter.

Detection: iodo-starch reaction.

6) Trypton-yeast broth. Esculine $1 \mathrm{~g} /$ liter.

Detection: Avicel TLC, $n$-BuOH -acetic acid - water ( $8: 2: 2)$, UV light (280 nm).

7) Trypton-yeast broth. Urea $1 \mathrm{~g} /$ liter.

Detection: ConwAY's microanalysis of diffusion method ${ }^{61}$, NessLer reaction.

8) L-Asparagine-casamino acid broth. Test sugar $1 \mathrm{~g} /$ liter.

Detection: $\mathrm{pH}$ indicator (BTB).

roseoviolacea A-5 (Table 4). Characteristics which distinguish strain A-3416 from standard strain A-5 of Actinomaaura roseoviolacea are:

(1) Reverse side of colony: changed to red with $0.05 \mathrm{~N} \mathrm{NaOH}$ (A. roseoviolacea A-5: violet).

(2) Nucleic acid hydrolysis: hypoxanthin from adenine: negative (A. roseoviolacea A-5: positive).

From these considerations, strain A-3416 is resonably recognized as a variant of $A$. roseoviolacea and designated as Actinomadura roseoviolacea var. rubescens nov. var. referring to the "red" substrate mycelium.

\section{Fermentation and Isolation of Antibiotic AB-64}

Strain A-3416 was grown on a slant of yeast-malt agar (ISP medium 2) for 2 weeks at $30^{\circ} \mathrm{C}$. 
Flask fermentations were run using $70 \mathrm{ml}$ of medium in 500-ml SAKAGUCHI flask. All fermentations were carried out at $30^{\circ} \mathrm{C}$ on a reciprocal shaker. Germination and fermentation medium: glucose $2 \mathrm{~g}$, defatted soybean meal $2 \mathrm{~g}$, soluble starch $1 \mathrm{~g}$, meat extract $0.1 \mathrm{~g}$, yeast extract $0.4 \mathrm{~g}, \mathrm{NaCl} 0.2 \mathrm{~g}$, $\mathrm{K}_{2} \mathrm{HPO}_{4} 0.05 \mathrm{~g}, \mathrm{CaCO}_{3} 0.4 \mathrm{~g}$, soybean oil $0.2 \mathrm{~g}$, tap water to $100 \mathrm{ml}, \mathrm{pH} 8.8$. Maximum yield was obtained by incubation for 10 days in $500-\mathrm{ml} \mathrm{SAKAGUCHI}$ flask containing $70 \mathrm{ml}$ of the medium and $3 \mathrm{ml}$ of 4 days old germinators.

The antibiotic produced was determined by paper disk method using Staphylococcus aureus P-213 (aminobenzyl penicillin resistant).

The cultured broth (7liters, $\mathrm{pH}$ 8.0) was separated continuously in S-type ultracentrifuge at $10,000 \mathrm{rpm}$. The supernatant broth was adjusted to $\mathrm{pH} 4.0$ with concentrated $\mathrm{HCl}$, and centrifuged. The precipitate $(110 \mathrm{~g}$, wet) was extracted two times with 1 liter of $80 \%$ aqueous acetone. The aqueous acetone extracts were concentrated to one fifth of its volume in vacuo. The aqueous solution was adjusted to $\mathrm{pH} 6.0$ with $\mathrm{NaOH}$, and extracted four times with the equal volume of $n$ butanol. The butanol extracts were concentrated to dryness in vacuo. The residue (crude active substance) was purified two times by chromatography on a column of Sephadex G-25. The residue was dissolved in $10 \mathrm{ml}$ of $0.1 \mathrm{~N} \mathrm{NH}_{4} \mathrm{OH}$, and charged on top a column $(5 \mathrm{~cm} \times 50 \mathrm{~cm})$ to which a suspension of Sephadex $\mathrm{G}-25$ in $0.01 \mathrm{~N} \mathrm{NH}_{4} \mathrm{OH}$ had previously been applied. The chromatographic development was carried out with $0.01 \mathrm{~N} \mathrm{NH}_{4} \mathrm{OH}$, and equal volume $(15 \mathrm{ml})$ fractions were collected. The antibiotic activity of the elutes was monitored by paper chromatography and its bioautogram. Antibiotic AB-64 was obtained after $1,100 \mathrm{ml}$ of the elute. The active fractions $(300 \mathrm{ml})$ were concentrated to dryness in vacuo. The residue (red powder) was dissolved in $2 \mathrm{ml}$ of dimethylsulfoxide and precipitated by addition with the equal or double volume of water. The red powder was purified further by reprecipitation from DMSO-water, washed with water and acetone, and filtered off and dried in vacuo. From 7 liters of the broth, $100 \mathrm{mg}$ of pure red powder (antibiotic $\mathrm{AB}-64)$ was isolated. The following $\mathrm{Rf}$ values were obtained by ascending paper strip chromatography : water, $0 ; 50 \%$ aqueous acetone, $0.59 ; n-\mathrm{BuOH}$ saturated with water, $0.54 ; n$ $\mathrm{BuOH}$ - MeOH - water ( $4: 1: 2), 0.74 ; n$-BuOHpyridine-water $(6: 4: 3), 0.72$.

\section{Physicochemical Properties of Antibiotic AB-64}

Antibiotic AB-64 is a pigment obtained as red powder having m.p. $275 \sim 277^{\circ} \mathrm{C}$ (dec.). The molecular weight of antibiotic AB-64 was not directly obtained owing to its low solubility in common organic solvents. The molecular formula $\mathrm{C}_{28} \mathrm{H}_{21} \mathrm{NO}_{8}$ of antibiotic AB-64 was confirmed indirectly by mass spectrometry and by the analysis of derivatives described below.

Antibiotic AB-64 is soluble in aqueous

Fig. 1. Procedure of isolation of antibiotic AB-64 Fermentation broth, pH 8.0

Precipitate adjusted to $\mathrm{pH} 4$ with conc. $\mathrm{HCl}$, centrifuged

extracted with $80 \%$ aqueous acetone

Aqueous acetone extract concentrated in vacuo

Aqueous solution adjusted to $\mathrm{pH} 6$ with $\mathrm{NaOH}$, extracted with $n-\mathrm{BuOH}$

$\mathrm{BuOH}$ extract

| evaporated in vacuo

Residue

gel filtration on Sephadex G-25, eluted with $0.01 \mathrm{~N} \mathrm{NH}_{4} \mathrm{OH}$

Active fraction evaporated in vacuo

Red powder (Antibiotic AB-64) 
Fig. 2. Ultraviolet and visible spectra of antibiotic $A B-64$ and its derivatives.

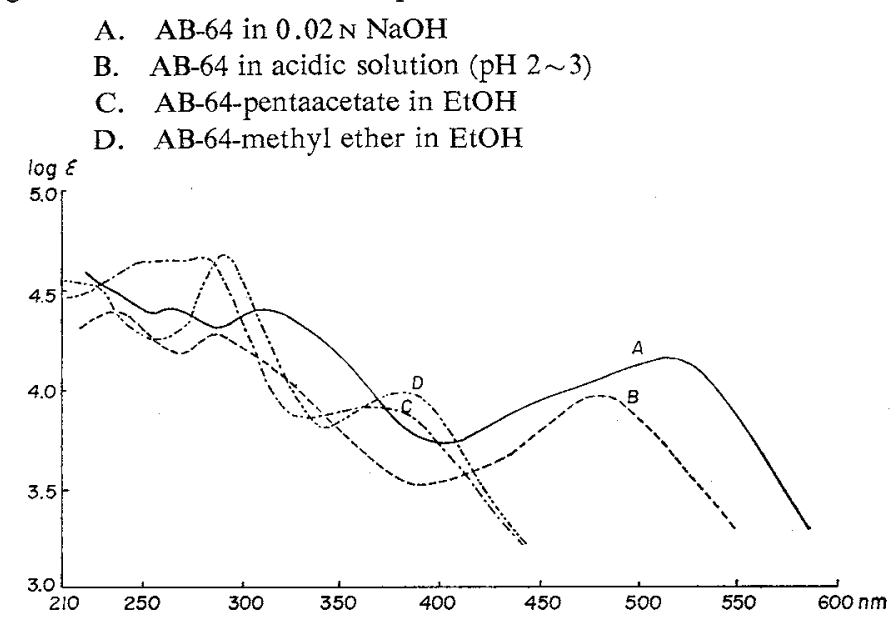

Fig. 3. Infrared absorption spectrum of antibiotic $\mathrm{AB}-64$ in $\mathrm{KBr}$ disk.

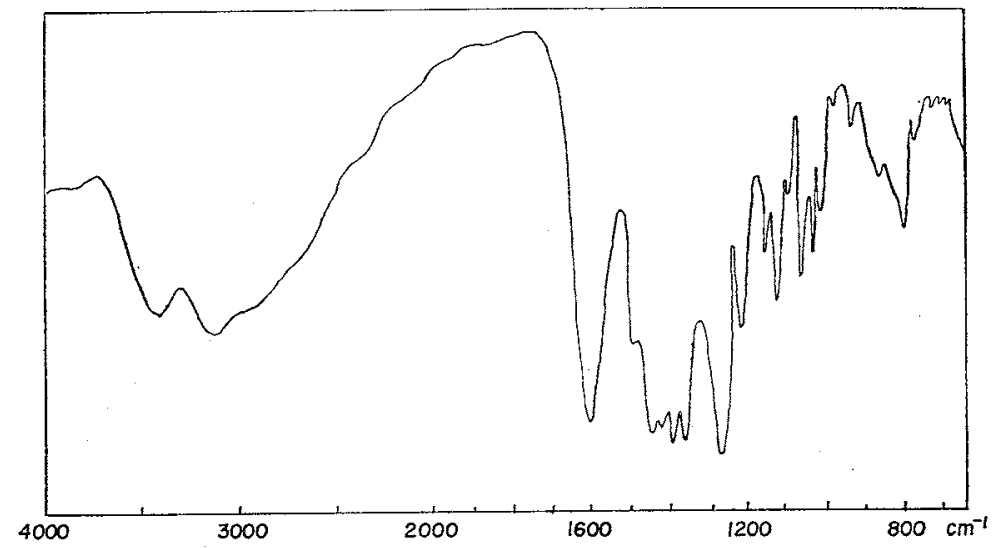

alkaline solution, e.g. ammonia and alkali hydroxides. The change of UV and visible spectra depending upon $\mathrm{pH}$ value of the solution as shown in Fig. 2 suggests that antibiotic AB-64 is classified as a phenolic $\mathrm{pH}$-indicator. In the IR spectrum, antibiotic AB-64 showed hydroxyl bands at 3400 and $3100 \mathrm{~cm}^{-1}$, and broad carboxyl bands at $1600 \sim 1630 \mathrm{~cm}^{-1}$ (Fig. 3). The latter indicated that the carbohydroxyl group of antibiotic AB-64 formed a strong intramolecular hydrogen bond. The NMR spectrum taken in diluted $\mathrm{NaOD}-\mathrm{D}_{2} \mathrm{O}$ solution showed two aromatic protons at $\delta 6.67$ $(1 \mathrm{H}$, singlet) and $6.94(1 \mathrm{H}$, singlet $)$, methoxyl protons at $\delta 3.50(3 \mathrm{H}$, singlet $)$ and aromatic $\mathrm{C}$-methyl protons at $\delta 2.03$ ( $3 \mathrm{H}$, singlet).

Antibiotic AB-64 was acetylated with acetic anhydride in aqueous ammonia followed with acetic anhydride-pyridine to give antibiotic AB-64-pentaacetate lactone, pale yellow prisms, m. p. $285 \sim 290^{\circ} \mathrm{C}, \mathrm{C}_{36} \mathrm{H}_{28} \mathrm{NO}_{13}$. Its NMR spectrum revealed the presence of two aromatic protons, one methoxyl group, one aromatic C-methyl group and five acetyl groups. In its mass spectrum, acetyl groups were broken down to a large extent by the sequence $\mathrm{M}-\mathrm{n} \times 42\left(\mathrm{M}=683\left(\mathrm{C}_{38} \mathrm{H}_{28} \mathrm{NO}_{13}\right)\right.$, $n=1$ to 5 in turn). This sequence was supported by each corresponding appropriate metastable 
peak. The IR spectrum of antibiotic AB-64-pentaacetate lactone exhibited the lactone and ester carbonyl bands at 1765 and $1720 \mathrm{~cm}^{-1}$.

On the other hand, antibiotic AB-64 was methylated with dimethyl sulfate followed with diazomethane to give antibiotic AB-64-permethyl ether, yellow prisms, m. p. $268 \sim 272^{\circ} \mathrm{C}$ (dec.). Antibiotic AB-64-permethyl ether was analysed for $\mathrm{C}_{34} \mathrm{H}_{38} \mathrm{NO}_{9}{ }^{+} \cdot \mathrm{CH}_{3} \mathrm{SO}_{4}{ }^{-} \cdot \mathrm{H}_{2} \mathrm{O}$, the molecular formula of which was confirmed by mass spectrometry showed a molecular ion peak at $m / e 589$ corresponding to $\mathrm{C}_{33} \mathrm{H}_{35} \mathrm{NO}_{9}\left(\mathrm{C}_{34} \mathrm{H}_{38} \mathrm{NO}_{9}-\mathrm{CH}_{3}\right)$. The presence of monomethylsulfate ion in antibiotic AB-64permethyl ether was reduced from its IR $\left(1220 \sim 1260\right.$ and $\left.740 \mathrm{~cm}^{-1}\right)$ and NMR spectrum $(\delta 3.75$, sharp singlet, $3 \mathrm{H}$ ). Further bands in the IR spectrum at $1740 \mathrm{~cm}^{-1}$ suggested the presence of carbomethoxyl group. Its NMR, spectrum showed two singlet aromatic protons, one aromatic C-methyl proton, one $\mathrm{N}^{+}$- methyl signal and eight methoxyl protons besides monomethyl sulfate protons.

Therefore, these spectral evidences led to the partial formulation of the structures I, II and III for antibiotic AB-64 and its acetylated and methylated products, respectively. Although we have no evidence on the residual part $\left(\mathrm{C}_{23} \mathrm{H}_{6}\right)$ of the AB-64 except the UV spectra shown in Fig. 2, it may be considered that $\mathrm{C}_{23} \mathrm{H}_{6}$ part comprises mainly a polycyclic aromatic ring.

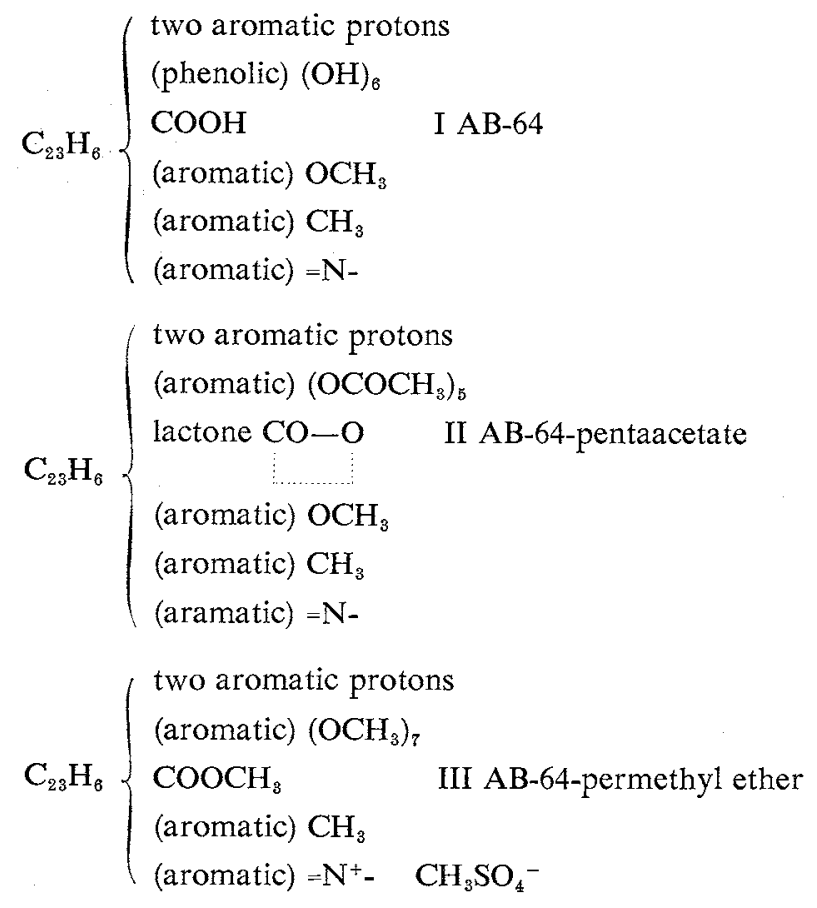

\section{Experimental}

$\mathrm{AB}-64(\mathbf{I})$

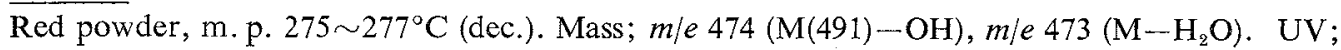
$\lambda_{\max }^{0.02 \mathrm{NaOH}^{2}} \mathrm{~nm}(\log e) 508(4.14), 310(4.41), 258(4.40)$. $\lambda_{\min }^{0.02 \mathrm{NaOH}^{2}} 400(3.70), 286$ (4.29) see Fig. 2. Anal. Calcd. for $\mathrm{C}_{26} \mathrm{H}_{21} \mathrm{NO}_{9}: \mathrm{C} 61.29, \mathrm{H} 4.55, \mathrm{~N} 2.75$. Found : C 60.53, H 4.55, N 2.75. $[\alpha]_{D}$ could not be measured for deep red color.

AB-64-pentaacetate (II)

AB-64 (46 mg) was dissolved in $7 \% \mathrm{NH}_{4} \mathrm{OH}(10 \mathrm{ml})$ and the solution was cooled in an ice-bath. 
Table 5. Antimicrobial spectrum of antibiotic AB64.

\begin{tabular}{|c|c|}
\hline Test organisms & $\mathrm{MIC}(\mathrm{mcg} / \mathrm{ml})$ \\
\hline Staphylococcus aureus Terajima & $1 *$ \\
\hline S. aureus ATCC 6538 & 1 \\
\hline S. aureus sp. S-21 & 0.3 \\
\hline S. aureus sp. S-23 & 1 \\
\hline S. aureus No. 5 & 1 \\
\hline S. aureus No. 6 & 0.3 \\
\hline$S$. aureus Miyamoto & 1 \\
\hline S. aureus $\mathrm{P}-7 \mathrm{C}(\mathrm{SM}, \mathrm{CP}, \mathrm{TC}-\mathrm{R})$ & 0.3 \\
\hline S. aureus $\mathrm{P}-32$ (SM, PC, TC-R) & 0.3 \\
\hline S. aureus $\mathrm{P}-213$ (ABPC-R) & 0.3 \\
\hline S. aureus FDA $209 \mathrm{P}$ (SM, STH-R) & 10 \\
\hline $\begin{array}{l}\text { S. aureus FDA } 209 \text { P JC-1 } \\
\text { (KM, STH-R) }\end{array}$ & 1 \\
\hline $\begin{array}{l}\text { S. aureus FDA } 209 \text { P JC-1 } \\
\text { (SM, STH-R) }\end{array}$ & 1 \\
\hline S. epidermidis No. 8 & 1 \\
\hline S. albus AKM & 1 \\
\hline Escherichia coli $\mathrm{K}-12$ & $>100 *$ \\
\hline Shigella flexneri 2 a EW 10 & $100 *$ \\
\hline Mycobacterium tuberculosis $\mathrm{H}_{37} \mathrm{Rv}$ & $>30 *$ \\
\hline Candida albicans ATCC 10257 & $>30 *$ \\
\hline Trichophyton mentagrophytes & $>30 *$ \\
\hline Trichomonas vaginalis $4 \mathrm{~F}$ & $30 *$ \\
\hline
\end{tabular}

* MIC: dilution method.

No mark MIC: streaking method.
Acetic anhydride $(10 \mathrm{ml})$ was added and the mixture was stirred vigorously at $60 \sim 70^{\circ} \mathrm{C}$ for 5 minutes. After cooling, the reaction mixture was extracted with $\mathrm{CHCl}_{3}$. The organic layer was washed with $\mathrm{H}_{2} \mathrm{O}$ and evaporated. The red residue $(45 \mathrm{mg})$ was acetylated with acetic anhydride and pyridine in usual way. The crude acetate was recrystallized from $\mathrm{CH}_{2} \mathrm{Cl}_{2} \mathrm{EtOH}$ to give pale yellow prisms $(29 \mathrm{mg})$, m.p. $285 \sim$ $290^{\circ} \mathrm{C}$. UV; $\lambda_{\max }^{\mathrm{EtOH}} \mathrm{nm}(\log e) 368(3.89), 283$ (4.66), 255(4.62). $\lambda_{\mathrm{min}}^{\mathrm{BtOH}} 328(3.84), 270(4.61)$, $\mathrm{NMR} ; \delta$ in $\mathrm{CDCl}_{3} ; 7.85^{\circ}$ (1H, aromatic proton), $7.38^{s}\left(1 \mathrm{H}\right.$, aromatic proton), $4.83^{\text {ss }}(2 \mathrm{H}), 3.92^{s}$ $(3 \mathrm{H}, \mathrm{OMe}), 2.65^{s}, 2.52^{s}, 2.37^{s}, 2.33^{s}$ (each $3 \mathrm{H}$, $\mathrm{OAc} \times 5), 2.16^{8}(3 \mathrm{H}, \mathrm{Me})$. Mass; $(\mathrm{m} / \mathrm{e}), 683\left(\mathrm{M}^{+}\right)$, $641\left(\mathrm{M}-42, \mathrm{~m}^{*} 601.6\right), 599\left(\mathrm{M}-84, \mathrm{~m}^{*} 558.8\right)$, $557\left(\mathrm{M}-126, \mathrm{~m}^{*}\right.$ 517.9), $515\left(\mathrm{M}-168, \mathrm{~m}^{*}\right.$ 476.2), $473\left(\mathrm{M}-210, \mathrm{~m}^{*}\right.$ 434.4). Anal. Calcd. for $\mathrm{C}_{38} \mathrm{H}_{28} \mathrm{NO}_{13}: \mathrm{C} 63.41, \mathrm{H} 4.25, \mathrm{~N} 2.05$. Found C63.25, H 4.28, N2.05.

\section{AB-64-permethyl ether (III)}

To a solution of AB-64 (236 mg) in $10 \%$ $\mathrm{NaOH}(5 \mathrm{ml}), \mathrm{Me}_{2} \mathrm{SO}_{4}(4.5 \mathrm{ml})$ and $10 \% \mathrm{NaOH}$ $(17 \mathrm{ml})$ were separately added dropwise with stirring at room temperature. After 8 hours, the reaction mixture was acidified with conc. $\mathrm{HCl}$ and extracted with $\mathrm{CHCl}_{3}$. The red residue obtained after the evaporation of solvent was methylated with diazomethane as usual and the crude product was chromatographed over silica gel with $10 \% \mathrm{MeOH}-\mathrm{CHCl}_{3}$ to give a yellow solid $(0.15 \mathrm{~g})$. Recrystallization from EtOH-ether afforded yellow prisms, m.p. $268 \sim 272^{\circ} \mathrm{C}$ (dec.). IR: $1740 \mathrm{~cm}^{-1}\left(\nu_{\mathrm{C}=0}\right), 1670 \mathrm{~cm}^{-1}\left(\nu_{C=N^{+}}\right), 1220-1260$ and $740 \mathrm{~cm}^{-1}\left(\mathrm{CH}_{3} \mathrm{SO}_{4}^{-}\right)$. UV; $\lambda_{\mathrm{max}}^{\mathrm{EtOH}} \mathrm{nm}(\log e) 382(3.96), 292(4.68), 224(4.54) . \lambda_{\mathrm{min}}^{\mathrm{EtOH}} 344(3.79)$, 260 (4.25). NMR $\left(\delta\right.$ in $\left.\mathrm{CDCl}_{3}\right) ; 7.62^{s}, 7.48^{s}$ (each $1 \mathrm{H}$, aromatic proton), 4.02s, 4.00s, $3.98^{s}$, $3.95^{s}, 3.60^{s}, 3.49^{s}, 3.37^{s}$ and $3.37^{s}$ (each $3 \mathrm{H}$, OMe $\left.\times 8\right), 3.37^{s}\left(3 \mathrm{H}, \mathrm{N}^{+}-\mathrm{Me}\right), 3.75^{s}\left(3 \mathrm{H}, \mathrm{MeSO}_{4}\right)$, and $2.26^{8}(3 \mathrm{H}, \mathrm{Me})$. Anal. Calcd. for $\mathrm{C}_{34} \mathrm{H}_{38} \mathrm{NO}_{0} \cdot \mathrm{CH}_{3} \mathrm{SO}_{4} \cdot \mathrm{H}_{2} \mathrm{O}: \mathrm{C} 57.29, \mathrm{H} 5.90, \mathrm{~N} \mathrm{1.91,} \mathrm{S4.37.}$ Found: C 57.39, H 5.54, N 1.91, S4.40.

\section{Biological Properties of Antibiotic AB-64}

The antimicrobial spectrum of antibiotic AB-64 determined by the dilution method and the streaking method is shown in Table 5. From these results it is evident that antibiotic AB-64 is active against gram-positive bacteria and resistant staphylococcci.

\section{Discussion}

Antibiotic AB-64 is a phenolic indicator substance, being orange in acid and neutral solutions and red in alkaline solution, and seems to be a heteroaromatic compound as shown by its UV, IR and NMR spectra. Due to similarities in UV and visible spectra and elemental analyses, antibiotic AB-64 was compared with known nitrogen-containing antibiotics having acid-base-indicating properties: cyanomycin ${ }^{10)}$, cinerubin ${ }^{10)}$, daunomycin ${ }^{10)}, 1$, 6-dihydroxyphenazine ${ }^{10)}$, iyomycin $B_{1}{ }^{10)}$, luteomycin ${ }^{10)}$, pluramycin ${ }^{10)}$, ractinomycin ${ }^{10)}$, rubiflavin ${ }^{10)}$, rubradirin ${ }^{10)}$, rhodomycin ${ }^{10)}$, ruticulo- 
mycin ${ }^{10)}$, streptorubin ${ }^{10)}$, streptovaricins ${ }^{10)}$, trypanomycin ${ }^{7)}$, violarins ${ }^{10)}$, and xanthomycin ${ }^{10)}$. But, the UV maxima characteristic, melting point and molecular formula of antibiotic AB-64 were not accorded with that obtained in these antibiotics. Red pigments with the methoxytripyrrole nucleus of prodigiosin (prodiginine) ${ }^{8.9}$ ) have been isolated from Actinomadura madura and $A$. pelletieri. These pigments are soluble in benzene, chloroform and hexane, but antibiotic AB-64 is not soluble, and the UV maxima of these pigments are not observed in antibiotic AB-64. Therefore, antibiotic AB-64 is a new antibiotic which differs from other known antibiotics.

\section{Acknowledgements}

The authors express deep thanks to Dr. H. Nonomura, Faculty of Engineering, Yamanashi University, for his kind guidance and valuable advice on the taxonomical studies of strain A-3416 and the supply of the type culture (A-5), and Director Dr. H. Takamatsu, Dr. Y. Yoshimura and Dr. H. Nishimura, Research Laboratories, Dainippon Pharmaceutical Co., Ltd., for their encouragement throughout this work. Thanks are also due to the members of Analytical Center and Chemotherapy Laboratory of our research laboratories for microanalyses, spectroscopic measurements and MIC testings respectively, and Mr. M. IMAI of our laboratory, for his cooperation during the screening course.

\section{References}

1) Nonomura, H. \& Y. Ohara: Distribution of Actinomycetes in soil. XI. Some new species of the genus Actinomadura LeChEvAlier et al. J. Ferment. Technol. 49: 904 912, 1971

2) Nonomura, H. \& Y. Ohara: Distribution of Actinomycetes in soil. IX. New species of the genera Microbispora and Microtetraspora, and their isolation method. J. Ferment. Technol. 49: 887 894, 1971

3) BOone, C. J. \& L. PINE: Rapid method for characterization of Actinomycetes by cell wall composition. Appl. Microbiol. 16: 279 284, 1968

4) Lechevalier, M.P. \& H. Lechevalier: Chemical composition as a criterion in the classification of aerobic actinomycetes. Inter. J. Systematic Bact. 20: 435 443, 1970

5) Shirling, E. B. \& D. Gottlieb: Methods for characterization of Streptomyces species. Inter. J. Systematic Bact. 16: 313 340, 1966

6) Conway, E. J.: Micro-Diffusion Analysis and Volumetric Error. pp. 87 123, Crossbey Lockwood \& Son Ltd., London, 1950

7) Fleck, W.; D. Strauss, C. Schönfeld, W. Jungstand, C. Seeber \& H. Prauser: Screening, fermentation, isolation and characterization of trypanomycin, a new antibiotic. Antimicr. Agents \& Chemoth. 1: 385 391, 1972

8) Gerber, N.N.: Prodigiosin-like pigments from Actinomadura (Nocardia) pelletieri and Actinomadura madura. Appl. Microbiol. 18: 1 3, 1969

9) Gerber, N. N.: A novel, cyclic tripyrrole pigment from Actinomadura (Nocardia) madura. Tetrahedron Letters 1970-11: 809 812, 1970

10) Umezawa, H.: Index of Antibiotics from Actinomycetes. Tokyo Univ. Press, 1967 